\title{
A piece of the mosaic: Gypsies in the building of an intercultural Europe ${ }^{1}$
}

\author{
Una pieza del mosaico: gitanos en la construcción \\ de una Europa intercultural
}

SIMONA SIDOTI

ANTHROPOLOGIST

\begin{abstract}
The article proposes a critical approach to the notion of interculturality in the context of the geopolitical and social transformations that marked the transition from the nation-state system to the birth of a common European identity.

In the European society the demarginalisation of territorial and identification borders raises the question of cultural differences and the need to redefine the new criteria for social inclusion. In this perspective, the process of European integration finds its own testing ground in social policies designed to cultural minority. The article focuses precisely on the case of Gypsy communities, exploring the symbolic and political mechanisms that have historically compromised public image of Gypsies through the 'nomad theory' by considering nomadism as part of an inherent identity.

The reproduction of this stereotype is at the basis of a social stigma of Gypsy groups, perceived as a public order problem that is reflected in national and supranational politics according to the tendency to consider Gypsies as incapable of decision making and not interlocutors on issues such as health, education and housing.

In this text, the author aims to examine these aspects of social exclusion of Gypsy communities and the fault lines of their Europeanisation process, emphasizing their deep roots in the historical and social structure of Europe and their political migration as a creative adaptation strategy to the historical-economic conjunctures.

In this framework of reference, interculturality becomes an analytical and political tool that is capable of overcoming the conflicts between the majority society and minorities and a project able to oppose to the ideologies of difference that transform the cultures into abstract and incommunicable entities.
\end{abstract}

Keywords: interculturality, Europe, Gypsy communities, cultural minority, mobility, labelling.

\section{Resumen}

El artículo propone un acercamiento crítico a la noción de interculturalidad en el cuadro de las transformaciones sociales y geopolíticas que han caracterizado el paso del sistema estado-nación al na-

1 Translation by Mary Savage. 
cimiento de una identidad comunitaria europea. En la actual sociedad europea la des-marginalización de los confines identitarios y territoriales se eleva la cuestión de las diferencias culturales y la necesidad de redefinir nuevos criterios de inclusión social. En esta perspectiva el proceso de integración europea encuentra uno de sus bancos de prueba en las políticas sociales dirigidas a aquellas comunidades consideradas minorías culturales. El artículo se centra en particular en el caso de las comunidades gitanas, examinando los mecanismos simbólicos y políticos que han determinado históricamente una representación negativa suya por la teoría de un nomadismo consustancial a la identidad gitana. La reproducción de este estereotipo es la base de un estigma social de los gitanos, percibidos como un problema de orden público y se refleja en las políticas nacionales y supranacionales que continúan sin considerarlos interlocutores activos en la elección de estrategias pertenecientes a la esfera de la salud, de la educación y de la vivienda. En el texto se discuten estos aspectos unidos a la exclusión social de los gitanos y los puntos débiles de su integración europea, subrayando su pertenencia histórica a Europa y valorando su política migratoria como expresión de una modalidad creativa de adaptación a las coyunturas histórico-económicas. En este marco de referencia, la interculturalidad se convierte en un instrumento analítico y político capaz de superar los conflictos entre sociedad mayoritaria y 'minoría cultural' y a su vez en un proyecto capaz de oponerse a aquellas ideologías de la diferencia que transforman las culturas en entidades abstractas e incomunicables.

Palabras clave: interculturalidad, Europa, comunidades gitanas, minoría cultural, movilidad, etiquetamiento.

The European scenario raises numerous points for reflection on and analysis of the effects that hyper-globalisation (Appadurai, 2006) has on the lives of individuals and their group identification and affiliation. Hyper-globalisation has led to the right to social citizenship and the demarginalisation of economic, political and cultural borders, the framework on which the nation-state system of modern Europe has been constituted.

Before the transformations spawned by the appearance of specialised transnational systems, the nation-state was the only unit of development, grounded on the conception of territorial and social homogeneity expressed through dichotomous poles, such as centre-periphery, opening-closure, inclusion-exclusion. Historically, belonging to a territory aligned the limits of social rights with the boundaries of the nation-state (Ferrera, 2004), by using the physical and symbolic space of citizenship as an absolute paradigm confirming recognition of the individual within a community of citizens and, at the same time, separating out individuals who do not share this feeling of common national identity. As Maurizio Ferrera has explained, within physical space citizenship is largely the key to access other more specific spheres of collective interaction related to employment, education, social welfare and, therefore, to the rights associated with these spheres. In practice, these rights have strengthened cultural identities and a willingness to feel as though one is a citizen of a state that shares resources and duties, the purpose of which are to provide social and political cohesion.

The idea of the nation state, in fact, has been fed by the ideology of belonging to a "national ethnos" (Appadurai, 2006) that incorporates the symbolic dimension of 
social citizenship and today represents, in the context of the new architecture of the European Union, the true Achilles' heel of European citizenship in its acceptance of the community ethnos as opposed to the state ethnos.

A reflection on the 'political' content of interculturality has arisen out of an urgent need to interpret the transformations of social citizenship generated by intercultural contact within the new 'European polis'. The recognition of interculturality as a political project also implies recognition of the current need to strengthen social solidarity and resolution of conflicts between social groups. If, on the one hand, the process of European integration has extended previous practices of solidarity based on national territoriality, on the other hand, the advance of globalisation increases the need for citizens to recognise themselves as part of a group that still identifies with belonging to a community, considered as a repository of identity. The cultural reference for individuals and communities must be at the same time national, European and intercultural. The foundation for this interculturality, therefore, is determined by interaction between different national traditions whose identities are currently undergoing a process of fragmentation. In parallel, the rhetorical language of assimilationist policies has made notions such as diversity, equal rights and social dignity meaningless, by placing them within an ideology of intercultural encounter that feeds on empty labels. However, as long as socio-cultural differences continue to be the core problematic of the twenty-first century, communication between researchers and policymakers will have to be increasingly dialogical and strive to critically review the concepts of culture, diversity and ethnicity. In line with these reflections, the idea of an interculturality rooted in politics focuses precisely on the right of all citizens to equal access to social resources, with respect for their cultural uniqueness and their right to "non-excluding interculturality" (Achilli, 1998).

Because the European community is still in construction, scientific research must follow the line of studies analysing intercultural relationships and their recomposition in new forms of European integration. Following this rationale, we might consider that the recent outbreaks of phenomena such as intolerance of and discrimination against Gypsy groups provide the opportunity to describe the microfactors that should form the basis for European social restructuring.

In order to learn which factors underlie this social stigmatisation, we must take an interdisciplinary approach to study the Gypsy minority, and assess the impact that European integration has had on relationships between these groups and the societies in which they come into contact. Gypsies are an example of a European community whose cultural identity is rooted in the European socio-political system, although politicians tend to exclude them from the Europeanisation process. A scientific approach that aims to shed light on the conflict and the gap between these communities and the predominant society is fundamental to an effective European 
strategy that can respond to the changes in today's society and provide the policymaking community with the theoretical and practical tools to actually develop a participative model of European integration.

Some historical and sociological issues help to frame the boomerang effect of European policies in the construction of Gypsy citizenship; these concern: 1) the dissipation of nation-building frontiers; 2) analysis of the symbolic mechanisms that have determined processes of social exclusion of Gypsy communities; 3) the ethnification of Gypsies; 4) the construction of a Gypsy identity as nomads in the media and in government policies; 5) the political-institutional responses designed to integrate communities; 6) the influence of community law and national legislative platforms on Gypsy groups; 7) fault lines in the European integration process and Gypsy Europeanisation.

These are important issues in the field of academic research, providing knowledge that must be disseminated among policymakers and European society in general in order to help reduce the prejudices that underlie the difficult coexistence with Gypsy groups.

The collapse of national ideology has led to radical changes in the way we understand political geographies and the movement of goods and people within Europe. The opening up of territorial boundaries and the weakening of national identities manifest in cultural roots mark a major crossroads for European unity: on the one hand, the new international regulations have altered conditions of access to economic and material resources, inevitably aggravating growing inequalities between nations, classes and social groups. On the other hand, the intensification of migratory flows within diffuse territorial boundaries raises questions of lost identity markers and the reification of a new social category of 'stranger' - no longer the comforting 'internal stranger' (Simmel, 1908) - who through his or her 'exoticism' is capable of re-establishing the boundary between us and them and reproducing the border.

Redefining citizenship to accept supranational social interaction is an inevitable challenge in the European integration process. The task of a united Europe is not only to destructure and restructure previous welfare state arrangements, but to integrate or, put another way, open up the components of its supranational identity to dialogue. Technically, this dialogue takes place through the legal, financial and social instruments that Europe has put in place to achieve the four cornerstones of free movement: workers, goods, services and capital. However, in designing European intercultural integration, a fundamental challenge still remains with regard to the individuals, communities and social groups that inhabit this sphere of community citizenship.

The 'intercultural policy' project is aimed specifically at the way in which a panEuropean humanity can be constructed through the interpretation of the symbolic and cultural mechanisms that act implicitly to determine the status of European 
citizens in those communities that are known as cultural minorities. Indeed, the question of intercultural integration finds its own testing ground in the social dimension and in the criteria of belonging to a European citizenry. It is here that vital implications for the future of Europe converge, not only with regard to citizens' civil, political and social rights, but also and above all, the right to choose ones own cultural and geographical roots.

Within this mosaic of economic, legal, political and social parameters that intersect on national and supranational planes, the integration process is an essential tool with which to turn the Europeanisation of citizenship into a condition that produces real changes in citizens' lifestyles. We should re-examine the landscapes of hyper-globalisation, and explore through microscopic analysis, the social make up in Europe, in which all groups contribute through their cultural diversity and agency.

In response to the question of who, today, are European citizens and who are Europe's strangers, we must go beyond 'simply' confirming the multilevel changes to European architecture: state market borders have expanded and are more porous; social rights are extended through the creation of new legal entities; new forms of 'collective redistribution' have been introduced; and mobility is embraced by different forms of free movement for citizens.

Europe is a 'possible' territory for people who move among multiple identities (Malouf, 1999) and without borders. We must not, therefore, think of people in terms of deterritorialised masses, constrained to feeling deprived of citizenship, stateless or not belonging, although clearly the stigma of being 'out of place' affects some social categories because, in the process of social construction, they evade and are beyond the control of established norms.

The question lies in the perception of difference and in the "fear of small numbers" (Appadurai, 2006) that, particularly now under the effects of a serious Europe-wide financial crisis, contribute to kindling xenophobia and racism and new practices of social apartheid. The sense of the purity of national ethnos lies behind the manipulation of this difference, regarded as a threat, and takes an anti-historical line by considering a Europe that is neither multicultural nor intercultural. The decline of the nation-state has not eliminated all nationalist ideologies, nor has it brought about a crisis of the state, except in terms of territorial and social homogeneity (Foucault, 1997). In contrast, the intensification of a state of 'uncertainty' of identity that moves across national borders makes 'the need for community' (Bauman, 2000) among European citizens even more urgent, and unconsciously encourages increasing invisible barriers between 'us' and 'others'. The movement of large masses of people generates a collective anxiety of recognition and translates into conflicts manifested at linguistic, religious, economic and social levels, revealing the current difficulty states face to absorb cultural diversity, whether locally or trans- 
nationally. The intensification of episodes of intolerance is breaking up Europe and raising intangible walls that undermine the very idea of social cohesion, and as a consequence, spread social and political rationales of social exclusion. This situation hinders the consolidation of European unity and, at the same time, is echoed in racist discourses that hide behind an idea of integration as the assimilation of the different 'other' among 'us'. In other words, the way the us-them frontier is reproduced appears as a thread running through the history of humanity, conditions European policies and appears to play a decisive role in the development of the "ideologies of difference" (Marta, 1994) and in European legislation related to differences from a perspective of containment.

The mechanisms that perpetuate the construction of ethnicity by dividing social groups into cultural majorities and minorities are linked to the intercultural aspect of relations between individuals and social groups. The story of the Gypsies raises not only the question of 'cultural minorities', but also the dynamics of coexistence and tensions that are established with the majority societies in the European space. Although this story recounts the experience of a people with deep roots in the historical and social structure of Europe, over the centuries it has resisted a process of removal by the official networks of a "European-nation-state", to gradually become a peuples-résistance (Asseo, 1989). In this sense, Gypsies are the other side of Europe, the side that exposes the weak points of integration-assimilation and points the way towards an alternative possible integration.

There are two different approaches in dealing with the question of European Gypsies, in which, according to the classic distinction between imposed identity and created identity (Baumann, 2004), two distinct rhetorical strategies are used to construct their group identity.

The first of these, imposed identity, focuses on difference and implies a 'marginalist perspective' that inevitably leads to differentiated treatment of these communities, both socio-politically and legally.

The second, however, recognises the capacity of a group to compose its own perception of identity. In the case of Gypsy groups, this capacity has been pushed aside in discourses promoting legal and social equality as a theoretical criterion for European integration, and increases the risk of the same differentialist logic arising in response to the obvious fact that in local and supranational policies, Gypsies are always considered as a social emergency that must be contained and resolved.

It is important to identify the factors that have played a determining role in shaping, both symbolically and materially, an imposed identity Gypsy groups and that help us understand the lack of coordination and interconnection in European programmes designed to support Gypsy 'minorities'. The way 'Gypsy identity' is classified, together with the legal system, have had a strong influence both on the non-Gypsy collective imagination, and in justifying anti-Gypsy terror through legal 
measures that are now judged unconstitutional. Historically, public order control bodies had a full gamut of legislative provisions available to them to deal with what were known as 'vagrants', a term that implicitly included Gypsy groups (Simoni, 2000), who were regarded as part of the "disturbing world of the street" (Sanga, 1995). In Spain, the Vagrancy Act (Ley de Vagos y Maleantes) of 4 August 1933 was passed unanimously with the consensus of all political parties of the Second Republic to control beggars, ruffians and pimps. In practice, it was used to repress those without means, and offers a good example of these legal provisions.

We take a dual approach in pursuing the idea of representing the political component in intercultural relations; on the one hand, the social iconography of the community and on the other, the area of European legislation in order to define the state of the Gypsy issue and unravel the connections between the way the Gypsies are theorised and the political and legal consequences this practice has for the European integration process.

We believe that pragmatic and technical responses will lead to the eradication of the cognitive and psychological barriers that for centuries have influenced perceptions about Gypsies in the context of European societies and the mental attitudes of their legislators.

The term 'nomads', used to refer indiscriminately to the whole range of Gypsy groups, has had an major bearing on their history and has acted as an absolute definition in descriptions of their cultural characteristics. According to the Latin nomen-omen Gypsies have been victims of labelling, regarded as 'essentially nomadic' and 'culturally rootless' and their mobility has been turned into an anti-social trait.

We must turn to explore some of the concepts that have frequently led to misunderstandings and perpetuated mistaken ideological positions, although anthropological studies of Gypsies have attempted to correct the profound cultural misunderstandings about Gypsies. "'The variety of Gypsy groups has been assimilated under the general umbrella term of 'nomads', which includes communities that for centuries have not had any kind of itinerant lifestyle, nor show any of the traits of "peripatetic communities" (Rao, 1987): a term used to refer to vagrant groups whose social structure is grounded in endogamy, the custom of marrying within the same group, and who make a living from providing services.

Not all Gypsy groups are travelling communities, and neither can all vagrants be classified as Gypsies. This synonymous use of Gypsy/nomad has helped to spawn differential treatment of Gypsies and has politically determined the adoption of nomadism as part of their identity.

Gypsies do not see permanence and nomadism as opposite poles, but rather as a continuum, frequently linked to survival strategies that in practice translate in a

2 The following paragraph is quoted from Sidoti S., 2004, "Gli insediamenti Rom e Sinti in Toscana", Rapporto di ricerca in Osservatorio Sociale, CD-ROM (ed) Fondazione Michelucci, Regione Toscana. 
readiness to move, a result of historical and social events or economic motives and not, as widely believed, because of an inherent nomadism in their Gypsy identity. Indeed, there are nomadic groups that become sedentary and vice versa, groups from what are generally sedentary communities that take up new forms of mobility. Furthermore, the category of 'Gypsies' encompasses a variety of culturally diverse groups, but which share certain common elements, and are thus based on a conceptually flexible structure that makes it impossible to identify sufficient traits needed to classify them. If we consider the romani language and nomadism as distinctive criteria, the possible combinations of these two elements give rise to a highly nuanced set of groups who do not all speak the Romani language, nor are all nomads (Piasere, 1995). Classification has more of an operative than a real value, or rather it is functional as an external differentiation imposed by non-Gypsy society, and as an internal differentiation by Gypsy groups, who use a range of ethnonyms to distinguish amongst themselves. The variety of groups becomes even more fragmented and more serious if, rather than internal distinctions, we consider the national legal categories that govern the treatment of Gypsies”. For example, the situation in Italy, a nation that has been cautioned on numerous occasions by European institutions for its unquestionable antiziganism, has led to a policy of "contempt" (Brunello, 1996) and the introduction of provisions for evicting from the so-called nomad camps. In Italy, an array of 'citizens' (Italian Gypsy citizens, Gypsy citizens of both European and extra-European countries and asylum seekers) is effectively ignored by the language of local administrations, and included under the established stereotype of the nomad. In the Collective Complaint No. 27/2004, the ERRC (European Roma Rights Center) denounced the discriminatory use of the term 'nomad' and the widespread antiziganism of Italian policies. In section 7.03, entitled 'Racial Segregation of Roma in Italy', it is clearly stated that the Italian authorities take a racial approach to the Gypsy issue by adopting laws that pursue the 'protection of nomadic culture' through the construction of 'nomad camps'. This 'solution' endorses the perception of Gypsies as nomads, justifying through political discourse the way the communities were living by presenting them as responsible for the degrading living conditions in the camps, as though they had no 'wish' to live in flats or apartments. The Italian media also uses the terms Gypsies/Roma/ nomads indiscriminately, with a particular emphasis on the term 'nomad' because, according to the ERRC, it is 'catchier' for journalists (ERRC, Collective Complaint v. Italy, systemic violation of the right to adequate housing).

Similar concerns were denounced in 2002 by the European Commission against Racism and Intolerance (ECRI, 2002), which condemned the deplorable living conditions of Gypsies in Italy and the clear division between these communities and the rest of Italian society. This separation seriously affects their chances of accessing areas of education, employment and health. 
The public image of Gypsies is controlled through labelling in press and government discourses: the political system and the media reinforce each other by disseminating antiziganism that increases fear of Gypsies and re-establishes a relationship of force based on the distance between 'us' and 'them'. The language used to represent Gypsies is not simply a description of this power relationship, but rather the very practice of the social and political subjection of Gypsies to the society in which they live.

The definition of Gypsies as nomads implies hegemony of control and the power of words as social action (Austin, 1962). This "demonisation of difference" (Hayes and Acton, 2007) through conditioning effected by discourses on Gypsies has direct effects on their right to education, employment, health and housing (Richardson, 2006-2007) and at the same time acts as a political springboard for votecatching during election campaigns or whenever popular consensus is needed.

The terms used to label Gypsy groups still carry historical weight and are indicators of their capacity to become immersed in the society they interact with, if we interpret them from an internal perspective. They are an expression of a self-recognition strategy, put into practice by the communities themselves as a guide through the varied geographical and social landscape of Gypsy cultures. The ethnonym can therefore provide references to place of residence, trade and religious belief. The cases of the Sinti and the Roma are examples of communities that add a geographical reference to their ethnonym, distinguishing between the Piemontese Sinti, Venetian Sinti, Sinti Estrexarja (Austria), Sinti Gačkane (Gackeno: Germany), Hervansko Roma (Hrvatski: Croatia), Roma Xoraxané (Xoraxáj: Turk), Roma Dassikanè (Dass: Serbia) (Melis 1995). Some groups are identified by their specific occupations - no longer practiced - that designate community membership. This is the case of the Rom Vlax (Vlax=Valacchia), sub-divided into many sub-groups, namely, kaldarara (tinkers), lovara (horse dealers), čurara (makers of brushes, combs, sieves, etc.), láutari (musicians), ursara (bear tamers), amongst others. In addition to geographical or trade related terms are those that distinguish between Muslim (xoraxané romá) and Christian Roma (dassikané Roma or gagikane Roma), although internally these two large religious sets are broken down into numerous sub-groups (Piasere 2004).

One of the aims of an intercultural political project is to analyse the social values embedded in this field of taxonomies, by considering classifications as "a powerful inductive framework" (Atran 1998) that allows us to break down the mechanisms of discrimination against Gypsies. For this reason, a group's name indicates the intercultural relationship and the depth of relationships communities have established with a given territory. To a certain extent, the provisions adopted to control these relationships depend on specific historical circumstances. This standardisation of communities put into practice by Europe is not an innocent or innocuous choice, and the debate about what definitions to adopt in reference to Gypsy communities 
reflects their recognition as a cultural minority, with their own rights and protection, a central issue on the political agenda of European institutions and the Council of Europe. Moreover, by recognising the diversity of groups and the history of their 'incorporation' in European social and geographical terrains, we acknowledge that this heterogeneity is not just a prerogative of Gypsies (McKinney, 2003), but a foundation of European culture, in which their roots are intrinsically intercultural.

Behind the 'invasion of borders' syndrome that, with the emergence of the nation-state, has reinforced "moral panic" (Acton, 1997) about Gypsies/nomads lies a basic historical and sociological statistic that cannot be ignored on the road to European integration: 80\% of the Gypsy groups in Europe are sedentary (Piasere, 2004; Liégeois, 2007) and only 20\% follow some type of nomadism/itinerancy, which is never an integral part of their culture, but rather an economic and political strategy they adopt to gain entry to non-Gypsy societies.

The sedentary society-nomadic society relationship is the crux of European social formation and highlights the urgent need for research projects that examine the issue of how the meaning of 'ethnicity' is manipulated to re-negotiate power relationships, thereby justifying the oppression of certain social categories. We would be supporting the 'perverse game' of ethnic identity if we were to consider Gypsy nomadism as a lifestyle directly rooted in their culture, or vice versa, their culture can only give rise to a nomadic lifestyle. This ethnification mechanism has been used to reinvent and 're-nomadise' Gypsies. Local administrations have responded to their housing needs with solutions that confine them in camps, or with other formula based on the conviction that Gypsies are 'resistant' to a sedentary lifestyle and should therefore be treated as a 'humanity' in perennial conditions of "displacement" (Rahola, 2007). This explains the core position of the 'nomad theory' in the national laws of many European countries whose main 'problem' has been the physical presence of Gypsies in their territory and the search for places to locate them where they do not compromise the public image of their cities. The French case with Law 2000/614 of 5 July 2000 relating to the Welcome and Housing of Travellers (Besson Law) is also a revealing illustration of the substantial discrepancy that can exist between a law's intention and its application. The law's failed attempts at integration confirm the reductionism implied in considering Gypsies solely as a public order problem, rather than attempting to understand how their mobility strategies are an expression of their way of (re-)creating their own 'place' in the social fabric. This disregard is also seen in the legal use of the term gens de voyage, used to camouflage direct discrimination against Gypsies, who become an indirect target for accusations of vagrancy.

This ambiguity surrounding Gypsy nomadism does not take into account the historical reasons and economic circumstances that have led many Gypsies to adopt a strategy of mobility, behind which can be recognised an external imposition 
exercised through social exclusion and governmental provisions. The opening up of borders in central and eastern European countries has created, also for Gypsies, the conditions for increased movement in pursuit of a better quality of life. Michael Guet, head of the Roma and Travellers Division of the Council of Europe, referring to the numerous changes in the mobility and freedom of movement of Gypsies, stresses that, "the 'mobility', 'movement' or 'migration' of Roma should not be confused with 'Roma nomadism', which is one of most frequent stereotypes found in the media" (Guet, 2010). Mobility is implicit in the European principle of free movement, but what makes Gypsy mobility more visible are the "ideological justifications of the obstruction of the free movement of labour and capital" (Acton, 2010). Institutional power does not recognise the political and economic significance of mobility in Gypsy social configuration, and through discriminatory policies and practices, undervalues the potential of their 'geographical imaginary'. Their political migration is an alternative way of appropriating space that can represent an opportunity for greater understanding of their wordview. In a world where people are more mobile and territorial and political borders are shifting, the way Gypsies settle in an intercultural society is an example and 'proof' of their flexibility to adapt to new contexts that has much to say to Europe. Gypsy mobility, however, is perceived as a domestic government problem more than a sociological phenomenon and Europe plays no role in this community integration.

Indeed, the latest events of antiziganism in France fall within a logic of deportation that violates Directive 2004/38/EC of the European Parliament and of the Council on the right of citizens of the Union and their family members to move and reside freely within the territory of the member states.

Viviane Reding, European Commissioner for Justice, Fundamental Rights and Citizenship, spoke clearly of deportation to condemn the ad hoc expulsions carried out by the French government against foreign Gypsies living in France and presented to the public as a measure justified by their 'voluntary return' to Romania and Bulgaria. These expulsions, carried out under national laws, are symptomatic of the weakness of European policies on 'Gypsy integration' and of the need to review the state of the question, which lies midpoint between local governmental actions and the European objective to achieve integration/inclusion, a process that demands precise long-term planning and the creation of instruments for a new pragmatic politics.

In reality, Gypsy mobility falls within the frame of the geopolitical transformations that have marked Europe through its major historical events, from the fall of the Berlin wall and the collapse of the Soviet bloc to the disintegration of the Balkan zone. In the 1990s, Gypsy visibility was symbolically amplified, and their numbers considered excessive rather than being seen as part of all other migration waves of communities from central and eastern Europe, where Gypsies represent 
a minority among other minorities. Since 1990, Gypsies have become a focus of attention for the Organization for Security and Co-operation in Europe (OSCE) (Piasere, 2003) which, under a Council of Europe directive, holds a central position in the discussion on the rights of communities. The contents of the Commission on Security and Cooperation in Europe (CSCE) Human Dimension Seminar on Roma of 20 September 1994 were in line with 'domestic and international legal and policy issues; equal opportunities and community relations', classified under its so-called Human dimension, which covers human rights, democratic institutions and the role of legislation.

On that occasion, it was stated that a high-level intergovernmental conference would be exclusively devoted to the situation of Gypsies, which it referred to as "an important and distinctive component of the mosaic of peoples that make up the population of our continent". A further important outcome of that meeting was that the theory on the protection of Gypsies would include their right to be different and right to be the same, thus recognising in this dual principle the importance of a good relationship with Gypsy communities. The vulnerability of Gypsies was implicitly linked with their condition of 'uncertain citizenship' - an essential issue broached in the 1994 seminar- which instituted the condition of 'strangers' inside their own countries and founded the semblance of a 'diaspora people", spreading across transnational borders. This first 'reception' of Gypsies in the European space excluded them from the list of 'national minorities', thus depriving them of a series of legal and social resources enjoyed by other groups whose cultural specificity was recognised. The controversy over the cultural minority status of Gypsies emerged with all its contradictions in 'Recommendation 1203 (1993) on Gypsies in Europe', dated 2 February 1993, which states that particular attention must be paid to the Gypsy minority in an attempt to construct "a genuine European identity" made up of different cultures.

The crucial point of the document lies in the very definition of Gypsy groups: "a true European minority", although they were not included in the definitions of linguistic and national minorities. This demand from the Parliamentary Assembly of the Council of Europe sanctions respect for the rights of Gypsies, recognised as a cultural non-territorial minority and covered by specific Council of Europe legislation on minorities. This question of their status highlights a clear division between opposing practices: whether to defend Gypsies on the grounds of cultural diversity, or on the grounds of equal rights, and draws a line between governmental attitudes during the 1990s and the attitude to Gypsies held during European expansion from 2004 to 2007 (Sigona, 2009). During this latter period a large number of Gypsies become part of the European citizenry 'by law'. From that moment on, Gypsies were no longer an 'external problem' (Dediu, 2007), but an integral part of the European project. Those years saw the flourishing of research initiatives promoted 
by the European Commission to monitor the situation of Gypsies. One example is the 2004 report "The Situation of Roma in an Enlarged European Union", the objective of which was to assess the conditions of the "largest ethnic minority" within Europe; in other words, to identify the implications of European expansion for inclusion policies for Gypsies in the eleven member countries of the Union. European efforts were directed to reducing 'direct' and 'indirect' discrimination of Gypsies, based on previous legislation designed to protect the fundamental rights of citizens "irrespective of racial or ethnic origin" (Race Directive 2000/43/EC), but placing greater emphasis on the social inclusion of Gypsies by recognising their identity as a cultural minority.

After 2004, European policy clearly shifted from rhetoric on the rights of minorities (Guglielmo, Waters, 2005) to an emphasis on the big issues of social inclusion, equality and the fight against discrimination (Vermeersch, 2007) which, in the case of Gypsy minorities, was tainted with pure antiziganism. Attention to the social inclusion of minorities was included in eligibility criteria for central and eastern European countries, although no reference could be made to uniform legislation on discrimination that would transform European standards. Barely one year after these notifications, on 28 April, 2005, the European Parliament resolution on the situation of Gypsies in the European Union (EP Doc. No. P6_TA(2005)0151) invited the European Commission to include counteracting Gypsy-phobia or antiziganism in the priorities for 2007 and to draft a communication that could coordinate and increase efficiency in EU efforts to improve the living conditions of Gypsies (Sigona, 2009). Underlying this need to go beyond the logic of anti-discrimination was the weakness of European legal instruments to promote Gypsies' rights. Interventions and directives from the Council of Europe, the OSCE and the European Union were not grounded on a homogenous legal corpus and were "part of the complex EU conditionality mechanism" (Dediu, 2007: 115).

In its resolution of 31 January 2008 on a European strategy for Gypsies, the European Parliament stated the importance of developing a "European Framework Strategy on Roma Inclusion aimed at providing policy coherence at EU level as regards the social inclusion of Roma and urges the Commission at the same time to shape a comprehensive Community Action Plan on Roma Inclusion with the task of providing financial support for realising the objective of the European Framework Strategy on Roma Inclusion" (EP Doc. No. P6_TA(2008)0035). What clearly emerges is that the approach adopted by European policies to reduce inequalities in the living conditions of Gypsies has not eradicated the structural causes of these inequalities, and has not managed to focus the responsibilities and the incapacity of institutional players in decisive interventions.

These considerations form part of a theoretical grounding of an intercultural perspective, which explores in the context of European "ethnopolitics" (Ver- 
meersch, 2007) the fault lines of Gypsy Europeanisation process, characterised by the persistence of individual and institutional discrimination, and widespread social exclusion.

The first of these fault lines concerns the relationship between the protection of minorities and anti-discrimination policies, which poses an ambivalent question for Europe and its institutional bodies: firstly, whether European regulations against discrimination are an effective instrument with which to defend minorities, and secondly, whether the attention to certain minorities - including Gypsies - does not reinforce the idea of differential, legally regulated treatment. The Gypsy situation is even more controversial than other groups, because their "ethnic image" reflects "a people dispersed across Europe, without a territorial homeland, but with a history, language and culture of their own. They are in a sense transnational" (CSCE Human Dimension Seminar on Roma, 1994: 47). After a period in which they were considered as a 'transnational European minority', practically a deterritorialised group, European governance is recognised in situations where domestic conflict occurs as a result of Gypsy presence, yet at the same time, their right to a tradition of nationality is ignored.

The black hole in the mechanism of Gypsy Europeanisation is rooted within the same process of nationalisation that always appears to be an external invention and not a democratic process experienced by the community. The dangers of Gypsy Europeanisation are closely related to the consequences of a nationalisation that has promoted "an authoritarian nationalist tradition" (Kovats, 2003). The dominant interests of the political elite have been met by this power mechanism, with which "a political community is constructed through the manipulation of vulnerable people" (ibidem). In order to harmonise policies on Gypsies across Europe, it is necessary above all to expose the mechanisms that have evaded the responsibility of institutions, and have rhetorically and practically supported indirect discrimination against the communities. In the field of European politics, Gypsies have been given a relevant position, but this has not always translated into positive strategy, which reveals the need to reinterpret certain aspects associated with the 'interculturality' of Gypsies in Europe.

The area of legal instruments, for example, is plagued with imbalances in many aspects: the correlation between domestic and European policies; the fragmentation of the European legislative apparatus and the lack of a homogenous legislative corpus that EU member states can refer to; the value of neutrality of laws in dealing with the ethnification of minority groups; the evocation of European legal standards that do not take into account the heterogeneity of groups according to their 'historical' identity. Finally, an additional legally relevant aspect is the way Gypsies' right to mobility is dealt with. Their mobility is implicitly protected by the EU under the principle of free movement, but the omission of a clear defence of the right 
to mobility in some way exposes the contradictions between the neutrality of the law and the hidden persistence of the conditioning that is effectively reproduced by legal regulations (Farget, 2010). In other words, although the driving force of democracy is undeniable, the legal system has played a role in spreading the negative stereotype of Gypsies through regulatory language (Simoni, 2009).

European opposition to discrimination and antiziganism sentiment presents another fault line in the coordination between European policies and domestic legal provisions regarding Gypsies. This inconsistency between the supra-national and the national dimensions is grounded in the Council of Europe's position in favour of standardising European policies on Gypsies, but at the same time it supports the view that legal provisions should be drawn up and adopted at a national level (Guet, 2010). The lack of homogenous shared norms and values reflects Europe's ambiguous role in dealing with the Gypsy issue, and this nuanced position does not clarify the relationship between macro and micro policies.

This lack of a common thread lies not only in the policies on Gypsies, but also in the field of studies into these groups that is characteristically fragmented and often driven by project proposals that respond to demands for intervention structures' at a local level. The European policy in this area has three main objectives: to identify good practices in relationships between Gypsies and the majority society; to strengthen their integration in line with their right to respect for their culture and equality of all citizens to fundamental rights; to contribute to building an international network of projects on Gypsies in line with existing national resources and activities (Koff, 2006).

These European directives clash, however, with the scant comparative research that traces a broad perspective of the Gypsies' situation in Europe. The state of research into Gypsy groups presents a panorama of research actions confined to specific issues that cannot easily apply ethnographic methodology, and thus the groups involved are relegated to the position of 'objects' of study. The anthropological approach, however, is the most appropriate, given that anthropology is a comparative discipline par excellence, that in societies' geographical and historical diversities uncovers the unvarying elements that give us a whole picture of the society. The object of the study of anthropology - according to the definition by Mondher Kilani - are the delimited social units that produce discord with the dominant society and, when distinguished from it, also allow us to see aspects related to the majority society (Kilani, 1989).

The scant attention to an 'anthropological culture' is therefore surprising, particularly in an area of research that appears to concentrate its efforts on conducting censuses on Gypsies demographies, with a clear interest in some types of 'sociological group inventory', rather than in "propriospect": a subjective, private way of 'seeing' and experiencing the world that sheds light on the culture of a group (Goodenough, 1981; Walcott, 1991). 
Discrimination against Gypsies is grounded on cultural misunderstandings that lie behind the failure of many policies, and on the persistent prejudices against them. The complex intercultural relationship typical of the Gypsies' situation in Europe concerns distinct spheres of the communities' public life which jeopardises their participation as citizens, describing how their visibility is manipulated through their social exclusion. If we understand interculturality as an abstract project, not grounded on politics and on interpersonal relationships, we run the risk of considering Gypsies' differences only in terms of culture and we are denying that this difference is also a social construction and that the similarities between Gypsies and non-Gypsies are much greater than the differences (Richardson, 2010). In the midst of this excessive imbalance, it is individuals who come into conflict, not cultures (Aime, 2004).

\section{References}

ACHILLI, E. L. (1998), "Vivir en la pobreza urbana. El derecho a una interculturalidad no excluyente", Revista Lote, http://www.fernandopeirone.com.ar/Lote/nro018/achilli.htm.

Acton, T. A. (1997), Gypsy politics and Traveller identity, Hatfield, University of Hertfordshire Press.

—(2010), "Theorising Mobility. Migration, Nomadism, and the Social Reconstruction of Ethnicity", Conference Proceedings, Romani Mobilities in Europe. Multidisciplinary Perspectives, International Conference 14-15 January 2010, University of Oxford, Refugee Studies Centre (RSC), 5-10, http://romanimobilities.files.wordpress.com/2010/06/ conference-proceedings.pdf.

Aime, M. (2004), Eccessi di culture, Turin, Einaudi.

Appadurai, A. (2006), Fear of Small Numbers. An Essay on the Geography of Anger, Durham, Duke University Press.

Asseo, H. (1989), "Pour une histoire des peuples-résistance", in Williams, P. (ed), Tsiganes: identité, évolution, Paris, Syros Alternatives, 121-127.

Atran, S. (1998), "Folk Biology and the Anthropology of Science. Cognitive Universals and Cultural Particulars", in Behavioral and Brain Sciences, 21 (4), 547-569.

Austin, J. L. (1962), How to Do Things with Words. The William James Lectures delivered at Harvard University in 1955, Oxford, Clarendon.

Bauman, Z. (2000), Missing Community, Cambridge, Polity Press.

-(2004), Identity. Conversations with Benedetto Vecchi, Cambridge, Polity Press.

Brunello, P. (ed), (1996), L'urbanistica del disprezzo, Rome, Manifestolibri.

Dediu, M. (2007), The European Union: A Promoter of Roma Diplomacy, in Nicolae, V., Slavik H. (eds), Roma Diplomacy, New York, IDebate Press, 113-130.

European Commission against Racism and Intolerance (ECRI), (2000), "Second report on France", Council of Europe, http://hudoc.ecri.coe.int/XMLEcri/ENGLISH/ Cycle_02/02_CbC_eng/02-cbc-france-eng.pdf. 
European Commission against Racism and Intolerance (ECRI), (2002), "Second report on Italy", Council of Europe, http://hudoc.ecri.coe.int/XMLEcri/ENGLISH/ Cycle_02/02_CbC_eng/02-cbc-italy-eng.pdf.

European Roma Right Center (ERRC), (2004), "Collective Complaint v. Italy, systemic violation of the right to adequate housing", http://www.errc.org/cms/upload/media/03/CB/ m000003CB.pdf.

European Commission. Employment and Social affairs, (2004), European Union Report "The Situation of Roma in an Enlarged European Union. Fundamental Rights and Discrimination", http://www.errc.org/cms/upload/media/00/E0/m000000E0. pdf.

European Commission against Racism and Intolerance (ECRI), (2005), Third report on France, Council of Europe, http://hudoc.ecri.coe.int/XMLEcri/ENGLISH/Cycle_03/03_ CbC_eng/FRA-CbC-III-2005-3-ENG.pdf.

European Parliament, (2005), "Roma in the European Union”, P6_TA(2005)0151.

European Parliament, (2008), “A European strategy on the Roma”, P6_TA(2008)0035.

FARgEt, D. (2010), “The Roma People's Mobility in Europe: a Challenge in Terms of Human Rights", Conference Proceedings, Romani Mobilities in Europe. Multidisciplinary Perspectives, International Conference 14-15 January 2010, University of Oxford, Refugee Studies Centre (RSC), 57-61, http://romanimobilities.files.wordpress.com/2010/06/ conference-proceedings.pdf.

Ferrera, M. (2004), "Verso una cittadinanza sociale 'aperta'. I nuovi confini del welfare nell'Unione Europea", in Rivista italiana di Scienza Politica, 1, 95-126.

Foucault, M. (1997), Il faut defendre la societe. Cours au College de France, 1975-1976, Paris, Gallimard.

Goodenough, W. (1981), Culture, Language, and Society, Menlo Park, CA, The Benjamin/ Cummings Publishing Company.

Guet, M. (2010), “Challenges Related to Roma Migration and Freedom of Movement in Europe", Conference Proceedings, Romani Mobilities in Europe. Multidisciplinary Perspectives, International Conference 14-15 January 2010, University of Oxford, Refugee Studies Centre (RSC), 77-83, http://romanimobilities.files.wordpress.com/2010/06/ conference-proceedings.pdf.

Guglielmo, R., Waters, T. W. (2005), "Migrating towards minority status. Shifting European policy towards Roma", in Journal of Common Market Studies, 43, 4, 763-86.

Hayes, M., Acton, T. (eds), (2007), Travellers, Gypsies, Roma. The Demonisation of Difference, Cambridge, Cambridge Scholars Press.

KILANi, M. (1989), Introduction à l'Anthropologie, Lausanne, Ed. d'en bas.

Koff, H. (2006), "La protección de los grupos étnicos en Europa Occidental: el estado de la ley contra la competencia política”, in Estudios Políticos, 29, 155-186, http://revinut. udea.edu.co/index.php/estudiospoliticos/article/viewFile/1301/1386.

Kovats, M. (2003), “The politics of Roma identity: between nationalism and destitution", in Open Democracy, http://www.opendemocracy.net/people-migrationeurope/article_1399. jsp.

LiÉgeois, J. P. (2007), Roma in Europe, Strasbourg, Council of Europe Publishing.

Malouf, A. (1999), Identidades Asesinas, Madrid, Alianza Editorial. 
Marta, C. (1994), "Ideologie della differenza e politiche d'integrazione a favore dei rom", in Ledda, L., Pau, P. (eds), Gente del mondo. Voci e silenz̧i delle culture zingare, Rome, Artemide, 33-38.

McKinney, R. (2003), "Views From The Margins. Gypsy/Travellers And The Ethnicity Debate In the New Scotland", in Scottish Affairs, 42, 13-31.

Melis, A. (1995), La Terza Metà del Cielo. Gli Zingari in Sardegna, Cagliari, GIA.

Piasere, L., Saletti Salza, C., Tauber, E. (2003), L'Educazione dei Bambini Sinti e Rom. Risultati Preliminari di una Ricerca Europea, in Scarduelli, P. (ed), Antropologia dell'Occidente, Rome, Meltemi, 103-134.

Piasere, L. (1995), "Introduzione. Storia di un nome”, in Piasere L., (ed), Comunità girovaghe, Comunità zingare, Naples, Liguori, 3-38.

-(2004), I Rom d'Europa. Una Storia Moderna, Bari, Laterza.

Rahola, F. (2007), "La forma campo. Appunti per una genealogia dei luoghi di internamento contemporanei", in Conflitti Globali, 4, 11-27.

RAO A. (1987), "The concept of peripatetics: an introduction", in Rao, A. (ed), The Other Nomads, Cologne, Bõhlau Verlag, 1-32.

Richardson, J. (2006), "Talking about Gypsies, the notion of discourse as control", in Housing Studies, Vol.21, 1, 77-96.

—(2007), "Policing Gypsies and Travellers", in Hayes, M., Acton, T. (eds), Travellers, Gypsies, Roma. The Demonisation of Difference, Cambridge, Cambridge Scholars Press.

- (2010), "Discourse dissonance: an examination of media, political and public discourse and its impact on policy implementation for Roma, Gypsies and Travellers at a local level", Conference Proceedings, Romani Mobilities in Europe. Multidisciplinary Perspectives, International Conference 14-15 January 2010, University of Oxford, Refugee Studies Centre (RSC), 166-196, http://romanimobilities.files.wordpress.com/2010/06/ conference-proceedings.pdf.

SAnGA, G. (1995), "Currendi Libido. Il viaggio nella cultura dei marginali”, in Piasere, L. (ed) Comunità Girovaghe, Comunità Zingare, Liguori, Naples, 367-385.

Sigona, N. (2009), I rom nell'Europa neoliberale: antiriganismo, povertà e i limiti dell'etnopolitica, in Palidda, S. (ed) Razzismo democratico, Milan, Agenzia X.

Simmel, G. (1908), Soziologie. Untersuchungen über die Formen der Vergesellschaftung, Leipzig, Duncker \& Humblot.

Simoni, A., (2000), "La mendicità, gli zingari e la cultura giuridica italiana: uno schizzo di tappe e problemi”, in Polis, Bologna, Il Mulino, 3, 371-390.

-(2009), "Appunti per una "lettura romani” del pacchetto sicurezza", in Diritto Immigrazione e Cittadinanza XI, 4, 217-230.

Vermeersch, P. (2007), "Ethnic minority protection and anti-discrimination in Central Europe before and after EU accession: the case of Poland", in Journal on Ethnopolitics and Minority Issues in Europe, 6(1), 1-21.

Wolcoтt, H. F. (1991), "Propriospect and the Acquisition of Culture", in Anthropology and Education Quarterly, 22 (3), 251-273. 